\title{
FORWARD GUIDANCE, PROS, CONS AND CREDIBILITY
}

\section{Maciej Ryczkowski*}

\begin{abstract}
The goal of the article is to verify the credibility of time contingent Forward Guidance (FG) as well as its possible time-inconsistency based on the rarely addressed example of the National Bank of Poland (NBP). The NBP's FG constitutes a unique case study as this measure in its 'Odyssean' form was not introduced to overcome the limits of further policy rates cuts. It allowed us to verify the FG's credibility and time-inconsistency by applying OLS and GMM estimated contemporaneous and forward looking Taylor type rules with interest smoothing. Our empirical evidence reveals that the annual period of FG in Poland was perceived as a credible promise by consumers. We found that time-consistency could have been an additional factor enhancing the considerable credibility of FG. The satisfying results of the NBP's FG appear to be especially interesting, in particular, when contrasted with the often unfavourable experience with time-contingent FG of prominent central banks. We suppose that to achieve this, the central bank should act with caution and the NBP indeed did so by specifying carefully the short horizon of the commitment to be able to abandon FG when the circumstances change. We also discuss FG by opposing its advantages and the drawbacks indicated in the subject literature.
\end{abstract}

Keywords: forward guidance, National Bank of Poland, unconventional monetary policy, zero lower bound on interest rates

JEL Classification: E44, E52, E58

\section{Introduction}

The National Bank of Poland (NBP) implemented inflation targeting in 1998. Since 2004 the continuous inflation target has been set at $2.5 \%$ with a permissible fluctuation band of $+/-1$ percentage point. The strategy had been modified before the Great Depression to enhance communication with the public, while after the crisis the alterations focussed on the possibilities of 'leaning against the wind' in case the asset bubble would be recognized, greater propensity to intervene in the foreign exchange market, emphasizing the need for flexible monetary policy, and acknowledging the role of macroprudential tools in stabilizing the economy. In consequence, the strategy of the NBP in its general form does not differ from the standards set by prominent central banks (Grostal et al., 2015).

After the crisis monetary authorities of major central banks broadened considerably communication with the public by explaining how monetary policy will be pursued in the future. In response to the weakening economic conditions, central banks

* Maciej Ryczkowski, Faculty of Economic Sciences and Management, Nicolaus Copernicus University, Torun, Poland (maciej.ryczkowski@wp.pl). 
of advanced economies adopted their accommodative monetary policies and lowered nominal interest rates to the historically and unprecedentedly low levels. As a result, some central banks almost depleted the possibilities to further stimulate the economic activity by a conventional monetary policy in the form of further cuts of nominal interest rates. It encouraged central banks to search for new tools to close the output gap. One of such tools was to augment communication with the public about the future policy rate path (den Haan, 2013). Forward Guidance (FG) is a new measure of communicating with market participants how monetary policy will be pursued in the horizon longer than to the next meeting of the monetary authorities, in particular, how nominal interest rates will be set by the central bank. The main goal of FG is to explain to economic agents how long they should expect easy monetary policy. It should allow to anchor mid- and long-run nominal interest rates at a low level to stimulate the real economic activity (Woodford, 2012), since decisions on savings and expenses of households and enterprises depend on the expected policy rates.

Following major central banks NBP introduced FG in July 2013 (NBP, 2013) despite the fact that Zero Lower Bound (ZLB) was not a binding constraint for interest rates. This created a unique case study of FG as this measure in its Odyssean form (Cambell et al., 2012) was introduced by major central banks to overcome the limits of further policy rates' cuts, which did not seem to concern NBP. It allowed us to verify the credibility of FG by applying classical Taylor type rules, which still seemed to hold for NBP. Credibility of FG is important because if the forward looking public is aware of the central bank's reaction function, market participants may not believe the commitment and the positive effects of FG will be subdued or may vanish (Filardo, Hofmann, 2014). Indeed, if the central banks' projections differ considerably from the market expectations, this may lead to serious mistakes in monetary policy (Svensson, 2015). The credibility seems to be of special concern, especially for NBP, as it is a central bank with no decades-long history of low and stable inflation.

While credibility is an ability of a central bank to persuade economic agents about its policy objectives and actions, one way to validate the credibility of FG is to inspect changes in the expectations about the nominal interest rate relative to the central bank's announcements. Baranowski, Gajewski (2015) based on micro-data stemming from the National Bank of Poland Survey of Professional Forecasters found evidence in favour of NBP's FG credibility. In the perception of most professional forecasters, the NBP's policy rates were not to be changed before the scheduled deadline.

We aim to verify whether FG and NBP were credible not only from the point of view of professional forecasters but also from the consumer perspective. For that purpose we check whether survey-based annual inflation expectations of consumers were in line with the FG's commitment. This is important since the ability of a central bank to commit credibly to future policies is believed to improve stabilization policies (Walsh, 2015). Additionally, we analyse whether the introduction of time-contingent FG created a wellknown time-inconsistency problem (Kydland, Prescott, 1977), as it was an often raised issue that was perceived to be a factor which may undermine the credibility of this measure 
(Filardo and Hofmann, 2014). This may happen when the forward-looking public is aware of possible incentives of a central bank to raise the interest rates. The reason is that if the economic recovery begins earlier than it was expected by the monetary board, the bank may be forced to abandon the policy of low interest rates, which may be interpreted as breaking the earlier promise (den Haan, 2013). The case study of Poland appears to be more interesting, in particular, when contrasted with the often unfavourable experiences with time-contingent FG of prominent central banks as the experiences of NBP can be read as satisfying. While we consider the data only for Poland, the findings are illustrative for the wider experience of countries that implement FG. As a result, our subsequent discussion is not limited to any specific country.

The second goal of the article is to point out that central bankers should be aware of medium- and long-term possible unintended consequences of FG. The awareness of its advantages and disadvantages is crucial to act not only effectively in the short run, but also responsibly in the long run. We assess FG's efficiency by comparing its advantages with disadvantages based on literature review. The literature on FG is relatively new and thus the evidence and empirical works on this communication tool are limited and frequently deliver ambiguous results. Moreover, the literature on FG usually concerns most developed countries, while NBP's FG literature is almost non-existent and thus this article fills in this gap. The analysis seems to be even more exceptional as the NBP's case study of Odyssean FG differs from the experience of other central banks constrained by ZLB.

\section{Data and Methodology}

FG's theoretical background is strongly supported by new Keynesian framework (Eggertsson, Woodford, 2003; Coenen, Warne, 2014). Taylor rules are integral part of DSGE models and therefore constitute a compatible instrument with FG's theory tool to investigate FG's performance (if policy rates are not constrained by ZLB). The estimated Taylor type rules mimic (albeit imperfectly) the behaviour of monetary policy. Naturally, they are useful only to the extent they are able to explain policy choices that in retrospect could be classified as good or bad (Kahn, 2012). Nevertheless, such simple rules in the opinion of Taylor and Williams (2010) have important robustness advantages over fully optimal or more complex rules and they work well in a variety of models.

To find the reaction function of NBP we estimate contemporaneous (Taylor, 1993) and forward looking Taylor type rules with interest smoothing (Clarida et al., 2000). The stationarity of the time series was analysed by ADF and KPSS tests. Contemporaneous Taylor rules are OLS estimated (Equation 1). Forward looking Taylor rules are GMM estimated (Equation 2) to overcome the least squares estimators' inconsistency when estimating models with rational expectations (Osinska, 2000, pp. 70-75). We estimate the latter rule (Equation 2) in two versions (for $k=1$ and for $k=4$ ) with lagged descriptive variables as instruments. Equation 2 includes 'a naive' rule with one quarter lead of the inflation gap $(k=1)$ as a proxy for the next quarter inflation gap expected by the central bank (with the assumption that the central bank is able to project perfectly the inflation gap one quarter ahead) and the rule with survey-based averaged expected 
inflation gap of consumers in the next 12 months $(k=4)$. This last specification $(k=4$, Equation 2) is used to verify whether the annual expectations of consumers during the period of FG were in line with the commitment. The credibility of FG would be confirmed if the bank's announcement of FG managed to persuade consumers to anchor interest rate expectations at the values declared in FG despite macroeconomic data would suggest the opposite. Remaining Taylor type rules serve as possible reaction functions to analyse viable time-inconsistency of the FG's commitment.

In order to find alternative specifications of the NBP's reaction function we add deviations of nominal exchange rates from their HP's trends (USD/PLN and EUR/PLN) and secondary market yields of 10-year bonds as a proxy for short-term interest rates' expectations following Mehra's (1997) proposal.

$$
\begin{aligned}
i_{t}=\bar{i}+ & \Phi_{s} i_{t-1}+\Phi_{\pi}\left(\pi_{t}-\bar{\pi}_{t}\right)+\Phi_{x} x_{t}+\Phi_{X R 1} X R_{U S D_{-} P L N}+\Phi_{X R 2} X R_{E U R_{-} P L N}+\Phi_{b} b_{t-1}^{10}+\varepsilon_{t} \\
& i_{t}=\bar{i}+\Phi_{s} i_{t-1}+\Phi_{\pi} E_{t}\left(\pi_{t+k}-\overline{\pi_{t}}\right)+\Phi_{x} x_{t}+\Phi_{X R 1} X R_{U S D_{-} P L N}+\Phi_{X R 2} X R_{E U R_{-} P L N}+ \\
& +\Phi_{b} b_{t-1}^{10}+\varepsilon_{t}
\end{aligned}
$$

for $k \in \mathrm{N}$,

where:

$i_{t}$ - National Bank of Poland's reference rate,

$\pi$ - Inflation rate,

$\bar{\pi}$ - Inflation target,

$x$ - Output gap,

$X R_{U S D_{-} P L N}, X R_{E U R_{-} P L N}$ - deviations of exchange rates of PLN against USD and EUR respectively from their HP filtered values,

$b^{10}$ - Secondary market yields of 10 -year bonds,

$\Phi, \bar{i}-$ Structural parameters,

$\varepsilon_{t}-$ Error term.

Inflation gap is the difference between the CPI inflation rate and the inflation target. Output gap is defined as a percentage deviation of real output from its HP filter with $\lambda=14,400$ (Robustness check for $\lambda=1,600$ and alternative specification of output gap: polynomial trend of order 3 with quadratic weights were also considered).

The quarterly data span from Q1 2000 till Q3 2015. The year 2000 was selected as the starting point, since at the beginning of this year a free floating exchange rate was introduced, despite the fact that inflation targeting had been implemented two years earlier. Data concerning policy rates, inflation expectations, exchange rates come from NBP, real seasonally adjusted GDP and secondary market yields of long-term (10 year) bonds come from the OECD, and CPI inflation is published by the CSO of Poland.

We use our data-set and estimated (by us) Taylor rules as well as Taylor rules found in the relevant literature for Poland to calculate alternative paths of policy rates, which are presumably in line with the NBP's reaction function. We take into account 
the rules based on quarterly data, which require similar explanatory variables we use to estimate our models. We consider contemporaneous and forward looking Taylor rules estimated by Baranowski (2011), GMM estimates of the monetary policy rule with the highest explanatory power of Vašiček (2009) and smoothing Taylor rule with actual inflation of Sznajderska (2012).

Next, during the annual period of the NBP's FG we verify whether prescriptions for the policy rates stemming from the considered rules diverged from the central bank's commitment of $2.5 \% .{ }^{1}$ First, after leaving out possible autocorrelation of time series due to short length of FG, we apply standard t-tests:

$$
t=\frac{\bar{X}-m_{0}}{S} \sqrt{n-1} \text {, where } s \text { is an estimator of the common standard deviation with }
$$

the null hypothesis that population mean equals $2.5 \%$ and $n$ is the number of observations. Second, for the whole time span Q1 2000 - Q3 2015 we estimate linear regressions:

$$
i_{t}=\alpha_{0 k}+\alpha_{1 k} \hat{i}_{t k}+\alpha_{2 k} \psi+\varepsilon_{t k} \text { for } k=1, \ldots, 7,
$$

where $\hat{i}_{t k}$ are the estimated values for the NBP's rate according to the considered Taylor rules, $\Psi$ is a dummy variable taking value one during the annual period of FG, otherwise zero and $\alpha$ are structural parameters, $\varepsilon$ is an error term. We verify whether $\alpha_{2 k}$ turns out to be statistically significant suggesting that the annual period of FG differed somehow from the remaining data, which would imply that the NBP's reference rate behaved abnormally in comparison to non-FG periods. Additionally, we verify whether $\alpha_{0 k}$ and $\alpha_{1 k}$ differed significantly from zero and unity respectively.

\section{The Concept of Forward Guidance, Its Pros and Cons}

The attempts to affect expectations by FG reflect the aim to meet the demand for democratic governance by forming a transparent decision-making process. FG was introduced by the RBNZ, which started announcing a path for the 3-month bank bill rate in 1997. What is new after the recent crisis is the scope and motivation to exploit this instrument. The earlier versions of FG were to present only forecasts of macroeconomic performance, while the latest modifications of this measure transformed unbinding forecasts into commitments.

The Odyssean kind of FG (after Cambell et al., 2012) is claimed to have been introduced first by the Bank of Japan (BoJ) in 1999, when the governor Masaru Hayami announced that zero interest rate policy will last until deflationary concerns subside tying BoJ to the given commitment like the mythological Oddyseus to the mast of the ship. This form of FG is a promise officially announced by the central bank that policy rates will be

$1 \quad$ NBP by implementing time-contingent FG did not want to announce change in the reaction function, which is in line with abundant empirical evidence that this central bank attaches primary importance to inflation stabilization. Therefore, the assumption taken in the methodology of the research that the reaction function remained constant during NBP's FG seems to be correct (Chapter 3). 
kept low for some time, lower than it would result from the standard rule of behaviour under the currently exercised monetary regime, even when recovery begins.

The assumed benefits of FG (Campbell et al., 2012; Gurkaynak et al., 2005) and of greater transparency (Walsh, 2013) explain why prominent central banks introduced FG into their extensively used crisis toolkit. The implementation of FG backed by new Keynesian theory may be confronted with mixed effects in the actual world. On the one hand, we have evidence of FG's efficacy in reducing uncertainty, lowering yields, providing favourable impact on financial variables or in creating the net stimulus to real activity and inflation, (for example, Bianchi and Melosi, 2014; Glick and Leduc, 2012; Swanson and Williams, 2014). On the other hand, however, influencing the expectations of the public about future policies experienced problems (Williams, 2013; Ueda, 2012; Svensson, 2010, 2015). Financial market responses to recent forms of FG (De Graeve et al., 2014) as well as the experiences of FED, BoJ, ECB and Riksbank clearly indicate that FG must be a credible commitment to be effective. Otherwise, the public will not trust the central banks' promise (e.g. Woodford, 2012).

However, providing for credible commitment to keep policy rates low even when the standard rule of behaviour under the currently exercised monetary regime suggests changing the policy rates, simply means that such a promise suffers from timeinconsistency and is a promise to follow a suboptimal monetary policy that decreases welfare. That led Paul Krugman to gaudy dub it 'a credible promise to be irresponsible'2.

In order to solve the time inconsistency problem, some leading central banks introduced into FG 'knockouts' (i.e. escape clauses). Conditional economic thresholds for exiting FG provide market participants with information to help them understand the circumstances under which the monetary policy accommodation would be maintained. FOMC members combined FG with unemployment rate, inflation and long-term inflation expectations. Threshold for unemployment rate was acknowledged also in the United Kingdom. Such a conditional escape clause may be perceived to be a clarification of a new reaction function (Bean, 2013). Nevertheless, NBP did not decide to implement this version of $\mathrm{FG}$, which could have helped to avoid time-inconsistency.

ECB did not decide to adopt state-contingent FG. Similar to the ECB, in the NBP the reason was that monetary authorities did not want to communicate the change in the reaction function, which would mean a temporal suspension of the monetary policy strategy. The ECB's and the NBP's decisions could have been explained not only by perceiving price stability as their primary objective (Cour-Thimann, Winkler, 2013), but also by state-contingent FG's drawbacks. First, it might be more difficult for the public to interpret. Second, with a regular turnover of monetary board members, it may paradoxically remain susceptible to time-inconsistency. Finally, state-contingent FG's impact still gives inconclusive results (Richhild, 2015).

Apart from the time-inconsistency issue, all kinds of FG are subject to criticism if considered from other perspectives. It is recognized that the positive impact of FG

2 http://krugman.blogs.nytimes.com/2011/03/18/credibility-and-monetary-policy-in-a-liquidity-trapwonkish/? r $=0$ 
in the standard new Keynesian framework is sensitive to model specification (Chung, 2015) and often highly overestimated, i.e. "Forward Guidance Puzzle" (Del Negro et al., 2012). De Graeve et al. (2014) explain it by possible misperception of the announced forward policy intentions under incomplete information. Carlstrom et al. (2015) attribute it to less forward looking sticky information Phillips curve or to sticky information economies, Caballero and Farhi (2014) blame for it the safety trap and McKay et al. (2015) provide evidence that if agents are exposed to uninsurable income risk and experience borrowing constraints, then a precautionary savings effect mitigates their responses to changes in future interest rates.

It is thus not clear whether provision of greater transparency by FG must necessarily be beneficial (Filardo and Hofmann, 2014). Bianchi and Melosi (2014) found that enhancing transparency indeed increases welfare. However, Morris and Shin (2002) show that high transparency under certain circumstances may move expectations away from fundamentals. A deterioration of forecast precision may appear when additional central bank information under near-risk neutrality of market participants leads to crowding out of private information acquisition (Kool et al., 2011).

Contrary to the outcomes of many New Keynesian models, the impact of FG may be diminishing in time. Kool et al. (2011) find at best weak evidence that FG allowed market participants to forecast short-term yields, while no such evidence was found for improvement in predictability of long-term yields (Lim, Goodhart, 2011). Likewise, Mckay et al. (2015) showed that the effect of FG about the interest rate 10 years in the future on current output is essentially zero.

Apart from above, FG may cause unintended consequences (White, 2013) particularly near ZLB. Rzonca (2014) argues that it impedes identification of insolvent debtors. Such a policy postpones the necessary restructuring of the economy and may expose central banks to various reputation risks (Filardo and Hofmann, 2014). Low policy rates usually encourage governments to increase public debt. Since financial crises are often followed by fiscal crises (Reinhart, Rogoff, 2011), FG increases the costs of the latter. Moreover, indebted governments may enact legislation limiting central bank's independence to maintain expansionary monetary policy (Meltzer, 2013). Belowequilibrium policy rates may distort investment decisions and may create environment vulnerable to speculative asset bubbles (Borio, Zhu, 2007). Furthermore, private agents may take higher risk to maintain their current rate of returns (Rajan, 2005). Low interest rates persisted by FG may cause destabilizing capital transfers, while exceptionally low values of core long-term government bonds may lead to financial mispricing and may damage the effective intertemporal allocation of resources (BIS, 2012). Uncritically low policy rates in response to widening credit spreads transfer the costs ultimately to savers (Curdia and Woodford, 2009). Finally, postponing to raise policy rates by implementation of FG gradually increases financial stability risks as the economy continues a recovery process and may fuel credit and asset price booms in emerging economies (BIS, 2012, Filardo, Hofamnn, 2014). 


\begin{tabular}{|c|c|}
\hline Advantages & Risks/Disadvantages \\
\hline $\begin{array}{l}\text { FG: } \\
\text { - does not require institutional changes to } \\
\text { - isisting monetary policy frameworks; } \\
\text { - removes uncertainty about future policy rates } \\
\text { and may reduce market participants' forecast } \\
\text { errors; } \\
\text { - provides information about the central bank's } \\
\text { reaction function in the new post-crisis } \\
\text { circumstances. } \\
\text { - Absence of FG (especially during ZLB or during } \\
\text { new unusual circumstances) may develop } \\
\text { misunderstandings about policy intensions; } \\
\text { - enhanced transparency may increase welfare; } \\
\text { - lowers expectations' volatility concerning } \\
\text { future behaviour of policy rates; } \\
\text { - some papers deliver satisfactory results of FG } \\
\text { for output gap stabilization, avoiding deflation, } \\
\text { flattening of the yield curve and raising output } \\
\text { even while ZLB; } \\
\text { - FG may enhance the effectiveness } \\
\text { of the monetary stimulus. }\end{array}$ & 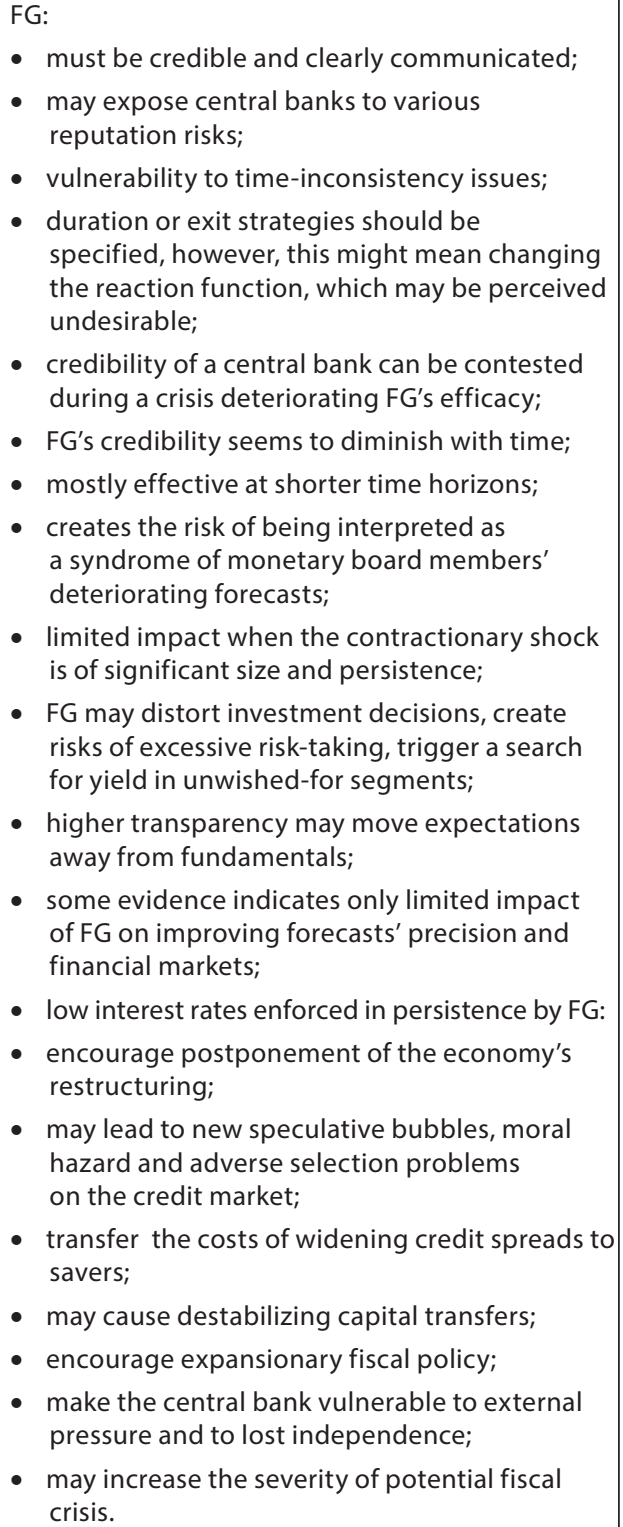 \\
\hline
\end{tabular}

Source: elaborated by the author

Despite caveats and mixed empirical results, Krishnamurthy and Vissing-Jorgensen (2011) prove that FG might be efficient in operating through the channel of lowering the yields on intermediate maturity bonds (Swanson and Williams, 2014). Nevertheless, 
its power seems to be too little to overcome the deflation and serious economic downturn. When not credible or when the market's expectations on future recovery are too pessimistic, the efficacy of 'the open mouth operations' would diminish or might bring results opposite to the expected. Therefore, Levin et al. (2010) justify that FG could be sufficient only for mitigating the effects of a 'Great Moderation' style shock. FG may be not enough for a Great Recession style shock or when deflationary expectations are anchored (Ueda, 2012). As a result, FG needs to be supported by quantitative easing, while there are grounds to believe that the commitment of the central bank to keep the short-term nominal interest rate at the ZLB amplifies the effects of asset purchases (Chen et al. 2012).

\section{Forward Guidance and the National Bank of Poland}

In June 2013 the Monetary Policy Council lowered rates by 0.25 p.p. and settled the reference rate at a record low level of $2.5 \%$, which ended the ongoing process of accommodation. At that time FG was introduced as a commitment to keep the rates unchanged until at least the end of 2013. However, in November 2013 the commitment was prolonged till the end of the second quarter of 2014. After that period, FG was abandoned and policy rates were soon lowered again in the third quarter of 2014 by 50 bps. Overall, NBP's FG lasted one year and despite the publication of more optimistic macroeconomic data and higher than expected inflation in July 2013, most analysts did not expect the change of rates earlier than in the announced commitment (NBP, 2013).

The Monetary Council implemented FG with a relatively short annual time horizon, as this form, according to the NBP (2013), was mostly clear and reliable. The Council was aware that credibility of FG for a considerably longer period of time would be limited due to uncertainty inherently inscripted into economic processes but also due to the reasons specific for Poland only. According to the Board, Poland was believed to be at the turning point of the business cycle, however, due to the global uncertainty and unstable external conditions, it was difficult to make longer commitments. Secondly, the Board pointed to the difficulties with making decisions in one institutional body within which members may differ in evaluation of the course of economic processes (NBP, 2013).

The important reason to implement FG in the opinion of Belka (2014) was to make the Monetary Policy Council and the NBP predictable. The Monetary Policy Council in July 2014 maintained the policy rates unchanged, however, resigned at the same time from exploiting FG explaining that future decisions will rest upon information stemming from evaluation of economic growth perspectives and inflation in the medium term.

\section{Empirical Results}

We obtained three standard Taylor rules' estimations, which may constitute the NBP's reaction function (Table 2). The estimated rules seem to be generally in line with the previous research conducted for Poland, despite the fact that the consensus about the exact values of the coefficients has not been reached. Therefore, with a view to increasing the robustness 
of the analysis, we investigate other specifications of Taylor rules found in relevant literature for Poland. Altogether we consider seven Taylor rules (of which three were estimated by us (Table 2) and the remaining four more were found in the literature).

Table 2 | Final Models with Estimates of Statistically Significant Coefficients of the NBP's Symmetric Taylor Rules, 2000Q1-2015Q3

\begin{tabular}{|l|c|c|c|}
\hline & $\begin{array}{c}\text { Reaction function 1 } \\
\text { Contemporaneous } \\
\text { Taylor rule }\end{array}$ & $\begin{array}{c}\text { Reaction function 2 } \\
\text { 'Naive' Forward } \\
\text { looking Taylor rule with } \\
\text { inflation lead one quarter, } \\
\boldsymbol{k}=\mathbf{1}\end{array}$ & $\begin{array}{c}\text { Forward looking Taylor rule } \\
\text { with market based 12 month } \\
\text { inflation expectations, } \boldsymbol{k}=\mathbf{4} \\
\text { (Reaction function 3) }\end{array}$ \\
\hline$\overline{\boldsymbol{i}}$ & $0.003(0.001)$ & $0.005(0.001)$ & $0.006(0.001)$ \\
\hline$\Phi_{s}$ & $0.90(0.02)$ & $0.87(0.02)$ & $0.85(0.02)$ \\
\hline$\Phi_{\pi} / E_{t} \Phi_{\pi+k}$ & $0.21(0.04)$ & $0.19(0.03)$ & $0.14(0.04)$ \\
\hline$\Phi_{x}$ & s.i. & s.i. & s.i. \\
\hline$\Phi_{X R 1}$ & s.i. & s.i. & s.i. \\
\hline$\Phi_{X R 2}$ & s.i. & s.i. & s.i. \\
\hline$\Phi_{b}$ & s.i. & s.i. & s.i. \\
\hline
\end{tabular}

Note 1: All the models are first-order autoregressive lag models, therefore, between the estimated coefficients in models (1)-(3) and the long-run coefficients we have the following relation $\widehat{\Phi}_{\pi}^{L R}=\left(1-\Phi_{s}\right)^{-1} \Phi_{\pi}$ (see Mills, 1990, p. 107).

Note 2: KPSS and ADF unit root tests indicate that all the analysed time series can be treated as stationary. For each of the time series at least one test allows to assume stationarity. As a robustness check due to the initial disinflation period in Poland we estimated models for first differences of the reference rate $\Delta \bar{i}$. The conclusions of the research were not altered.

Note 3: The estimates of the output gap coefficients $\Phi_{x}$ and their (standard errors) equalled 0.04 (0.05); $0.00(0.04)$ and $0.02(0.05)$, respectively.

Model 1: $R^{2}=0.98$, Adjusted R-squared $=0.98$, Breusch-Godfrey test for autocorrelation up to order 4: Test statistic: $L M F=3.051$, with $p$-value $=P(F(4,51)>3.051)=0.0249$; Alternative statistic: $T R^{2}=11.2$, with $p$-value $=\mathrm{P}($ Chi-square $(4)>11.2)=0.0244$; Ljung-Box $\mathrm{Q}^{\prime}=11.252$, with $\mathrm{p}$-value $=\mathrm{P}($ Chi-square $(4)>11.25)=0.024$; Model 2: $\mathrm{GMM}$ criterion: $\mathrm{Q}=0.147(\mathrm{TQ}=8.231)$, J test: Chi-square $(6)=8.231$ [p-value: 0.222 ], Model 3: $\mathrm{GMM}$ criterion: $Q=0.169(T Q=9.264)$ J test: Chi-square $(6)=9.264$ [p-value: 0.16 ]. In all GMM estimated models (i.e.: $2,3,4$ ) the $p$-value is associated with a Sargan's J test of the model's over-identifying restrictions.

s.i. statistically insignificant, standard errors in parenthesis

Source: elaborated by the author

In all three models a high degree of interest soothing with the $\Phi_{s}$ parameter above 0.8 can be noted. The high degree of interest smoothing in Poland is a typical result (Sznajderska, 2012; Vašiček, 2009). High $\Phi_{s}$ may be desirable to make the central bank history dependent, so that it can serve the bank's stabilization objectives (Woodford, 2003) it may reflect fears of disrupting capital markets, loss of credibility due to sudden considerable policy reversals, or the necessity for consensus building to support a change in monetary policy (Clarida et al., 1998). Nevertheless, high $\Phi_{s}$ may also be a syndrome 
of excessive gradualism (Caplin and Leahy, 1996) or might stem from spurious omission of important persistent influences on policy rate setting (Rudebusch, 2006), so the interpretation is not straightforward.

The estimated $\Phi_{\pi}$ coefficient in model 1 and $E_{t} \Phi_{\pi+k}$ coefficients in models 2 and 3 are positive and may be evaluated as correct from the economic standpoint. The values of $\Phi_{\pi}$ or $E_{t} \Phi_{\pi+k}$ are similar to those found in the literature for Poland and indicate strong commitment to stabilize the inflation (Baranowski, 2011). It must be noted that although in the short run the estimated coefficients on inflation gap are smaller than unity, in the long run the Taylor Principle would be fulfilled in all three specifications ${ }^{3}$. The long run effects of the inflation gap (in models (1)-(2)) according to the formulae in Note 1 below Table 2 are greater than unity and equal respectively 2.1 and 1.5. The exception is model 3, nevertheless $E_{t} \Phi_{\pi+4}$ is not statistically different from unity. Therefore, we conclude that all the models indicate (highly ${ }^{4}$ ) stabilizing monetary policy following the proposal that central banks should adjust policy rates more than proportionally with inflation. Such a result shall be of no surprise in inflation targeting regimes (Popescu, 2014). Similar values were noted also for the United States under Volcker and Greenspan (Clarida et al., 2000). The principle is necessary for the bank to target successfully the inflation, while in many monetary models meeting this criterion is necessary and sufficient for the existence of a determinate rational expectations equilibrium (Davig, Leeper, 2007).

The $\Phi_{x}$ turned out to be statistically insignificant in all models (alternative output gap measurement method: polynomial trend of order 3 with quadratic weights and HP's parameter $\lambda=1,600$ did not change the results). Not statistically significant $\Phi_{x}$ is in line with many empirical works concerning Poland and some other developing countries (Frömmel et al., 2011; Orlowski, 2010). It may indicate a strong commitment to keep the inflation close to the inflation target or a trial to gain credibility at the cost of output stabilization. This explanation seems to be particularly plausible for Poland as after the implementation of inflation targeting in 1998 there was an appreciable disinflation period. Nevertheless, the outcome seems surprising as short term output stabilization is believed to foster medium and long term price stability. Therefore, even central banks with official goal of stabilizing prices often do stabilize real economy (Wojtyna, 2004, p.140-161; King, 1997). Indeed, some new studies on Taylor rules for Poland indicate that output stabilization plays a role in influencing NBP's decisions on policy rates (Popescu, 2015, Caraiani, 2013).

We have not found statistically significant lagged secondary market yields of longterm bonds, which is in contrast to Hsing (2005) who obtained a considerable impact of the long-term interest rate on federal funds rate. This may be possibly due to the less sophisticated financial market structure and the less developed bonds market in Poland.

3 The long run coefficients are: Model 1: $\hat{\varphi}_{\pi}^{L R}=\frac{0.21}{1-0.9} ;$ Model 2: $\hat{\varphi}_{\pi}^{L R}=\frac{0.19}{1-0.87} ;$ Model 3: $\hat{\varphi}_{\pi}^{L R}=\frac{0.14}{1-0.85}$.

$4 \quad$ In the case of models (1) and (2). 
The exchange rates of PLN against USD and EUR turned out to be statistically insignificant. This may confirm the strong commitment of the NBP to stabilizing inflation by focussing on inflation and not confusing the public about the central bank's primary goal. In fact, the theoretical literature shows that there are few gains from adding exchange rate into Taylor rules (Leitemo, Söderström, 2005). As a result, in many empirical works the exchange rate in the NBP's Taylor rule is either not considered (Baranowski, 2011) or turns out to be statistically insignificant (Orlowski, 2010). The responsiveness to exchange rates is, however, not conclusive as some studies point to the statistically significant exchange rate in Poland (e.g. Popescu, 2015).

Figure 1 | Reference Rate and Its Values according to Different Models in the Sub-Period 2013Q12015Q3

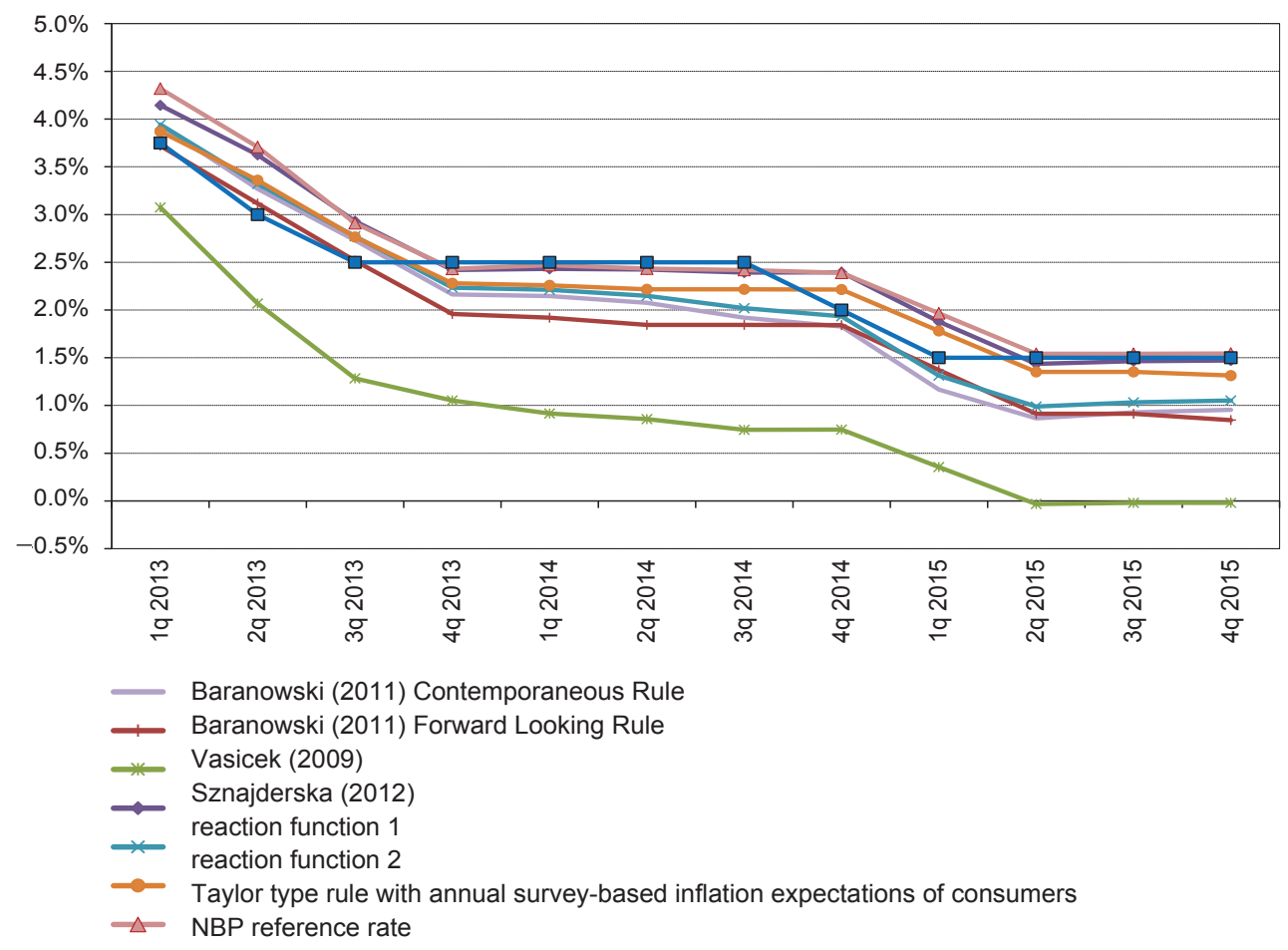

Source: own calculations

Let us notice that during the whole annual period of FG, the interest rates stemming from the Taylor type rule with annual survey-based inflation expectations of consumers as an inflation measure were almost identical with the commitment (Figure 1). Thus, the interest rates according to the estimated rule and based on their inflation expectations, were in line with FG's commitment. The Taylor type rule served as a tool to explain what interest rates are presumably expected by consumers given their inflation expectations. 
The result provides evidence that the consumers have believed the FG's announcement since inflation expectations of the consumers were in high compliance with the announced $2.5 \%$, despite the publication of more optimistic macroeconomic data and inflation higher than expected in July 2013. As a result, we may conclude that the NBP's FG turned out to be credible not only in the perception of most professional forecasters (Baranowski and Gajewski, 2015) but also in the judgment of consumers.

Next, in Figure 1 we compare the behaviour of NBP's reference rate and the policy rates which result from the six remaining Taylor type rules. Since time-inconsistency could possibly undermine the credibility of FG (Filardo and Hofmann, 2014) we verify whether the national bank faced a temptation to change the level of the policy interest rate during the FG period. The general outlook is that except for interest rates estimated by Vašiček (2009), all the remaining Taylor rules contribute to similar prescriptions for interest rates. The reasons behind the distinct values resulting from the model of Vašiček (2009) are possibly the use of a 3-month interbank interest rate as the short-term interest rate $i_{t}$ and the time span under the analysis (1997-2007) covering two years of noninflation targeting. In fact, we may spot that the FG period caused slightly tighter monetary conditions when compared with those resulting from the majority of Taylor rules. That seems to suggest a potential cost for the NBP in the form of deviations from the known Taylor rule. However, we argue further that the differences between FG's 2.5\% and the prescriptions stemming from the considered Taylor rules were not statistically significant.

Based on $t$ test, we have found that the differences between means of the reference rates stemming from the Taylor type rules during FG were statistically not different from the $2.5 \%$ commitment. Only in the case of Vašiček (2009) the mean differed significantly from the $2.5 \%$ - however, the rejection of the null hypothesis was with p-value $=0.041$. Moreover, $\alpha_{2 k}$ for $k=1, . ., 8$ all turned out to be insignificant, which confirms that indeed the annual period of FG has not differed from the remaining data. In all the considered Taylor rules $\alpha_{0 k}$ did not differ significantly from zero (with the exception of Vašiček, $2009, \alpha_{0 k}=0.0096$, std. error $\left.=0.001\right)$ and $\alpha_{1 k}$ did not differ significantly from unity (with the exception of Baranowski (2011) Forward Looking Rule, $\alpha_{1 k}=0.942$, std. error $=0.015)$. This proves that the period of FG was time-consistent, which could have been an additional factor that contributed to the evidenced credibility of NBP's commitment. Nevertheless, the effects of FG can be hardly distinguished from the effects of the policy rule.

In the second half of 2014, when circumstances to lower the policy rates appeared, FG was not prolonged and was abandoned, while the policy rates were soon lowered. It shows that when the cost of deviation from the reaction function became considerable, the NBP resigned from FG. FG was maintained only when the cost for the central bank of doing so was not meaningful. The statement of Chairman Belka (2013), therefore, seems to confirm this interpretation - he argued that the bank was cautious when implementing FG, which may be interpreted that the announced commitment could have been broadly in line with the reaction function. When it stopped doing so, FG was abandoned. 
The case study of the NBP provides evidence that time-contingent FG's promise turned out to be credible, in spite of the risks to credibility of particularly this version of FG, mentioned in the relevant literature. The results achieved by the NBP contrast with the frequent unfavourable experiences of some major central banks with time-contingent FG. The example of the NBP proves that time-contingent FG may become an efficient tool of anchoring interest rate expectations. To achieve this, a central bank should, however, act with caution and the NBP indeed did so by specifying carefully the horizon (usually short) of the commitment and by abandoning FG when the circumstances changed. In case the foresight will not be kept, FG may start to be interpreted by the public 'as an unreliable boyfriend' as some MPs felt it had sent mixed signals over the timing of future interest rate rises of the Bank of England. In this case the public may not trust the central bank's promise (for example, Neuenkirch and Siklos, 2014). Therefore, when this tool deviates from the known reaction function and the time-inconsistency problem arises, the situation may be relieved by implementing certain 'knockouts', however, at the cost of changing the reaction function or even the announced monetary strategy. This in turn questions the purpose of the threshold-based FG's implementation by central banks which do not wish to modify their monetary regime.

\section{Conclusions}

Poland is an interesting case study of FG as FG was introduced by major central banks to overcome the limits of further policy rates' cuts, while NBP was not constrained by ZLB. Our empirical evidence reveals that the commitment to keep the policy rates unchanged from July 2013 to July 2014 was perceived as a credible promise. The NBP fulfilled the commitment to keep policy rates low, which were close to the values suggested by the standard rule of behaviour under the currently exercised monetary regime. However, when the deviation from the reaction function became considerable, the NBP resigned from FG and lowered policy rates soon. This means that the NBP's FG did not suffer from the time-inconsistency. The time-consistency could have been, therefore, an additional factor enhancing the considerable credibility of FG's announcement, however, the impact of time-consistency can be hardly established.

Meanwhile, the relevant literature and experiences of central banks indicate that credibility of FG is a key factor affecting its potential efficacy. However, providing for credible commitment should be done with the greatest caution because especially time-contingent FG may suffer from credibility problems or time-inconsistency issues, which was already recognized by major central banks. The case study of the NBP provides evidence that problems associated with credibility and time-inconsistency are not a necessity. Presumably to avoid them, decisions on FG should be made with caution while the horizon of time-contingent FG should be relatively short. Otherwise, the longer the horizon of the commitment, the greater the probability that the official promise would deviate from the reaction function leading to time-inconsistency, which may be relieved by implementing other forms of FG, however, at the cost of changing the reaction function or the announced monetary strategy. 
Despite the evidence in favour of FG, the tool poses risks of unintended consequences in the medium and long run. Taking into account that FG is usually accompanied by large programmes of asset purchases, the joint consequences may compound and magnify positive as well as negative effects of non-standard measures. The awareness of the existence of both the advantages and disadvantages of FG appears to be important for central banks which should consider acting not only effectively in the short run, but also responsibly in the medium and long run.

\section{Appendix}

We presented evidence that long-run values of the estimated inflation gap coefficients in our first-order autoregressive lag models are given by the formulae: $\widehat{\Phi}_{\pi}=\left(1-\Phi_{s}\right)^{-1} \Phi_{\pi}$. Recursive calculation (while $\left|\Phi_{s}\right|<1$ ) leads to a situation, when in the $n$-th quarter the interest rate would be given by:

$$
\begin{aligned}
& \lim _{n \rightarrow \infty}\left(\Phi_{s}^{n} \times \bar{i}_{t}+\Phi_{s}^{n-1} \times \Phi_{\pi}\left(\pi_{t}-\bar{\pi}_{t}\right)+\Phi_{s}^{n-2} \times \Phi_{\pi}\left(\pi_{t}-\overline{\pi_{t}}\right)+\ldots+\right. \\
& \left.+\Phi_{s}^{2} \times \Phi_{\pi}\left(\pi_{t}-\overline{\pi_{t}}\right)+\Phi_{s}^{1} \times \Phi_{\pi}\left(\pi_{t}-\overline{\pi_{t}}\right)+\Phi_{s}^{0} \times \Phi_{\pi}\left(\pi_{t}-\overline{\pi_{t}}\right)\right)= \\
& =\lim _{n \rightarrow \infty}\left(\Phi_{s}^{n} \times \bar{i}_{t}\right)+\lim _{n \rightarrow \infty}\left(\Phi_{s}^{n-1} \times \bar{i}_{t}++\Phi_{s}^{n-2} \times \Phi_{\pi}\left(\pi_{t}-\overline{\pi_{t}}\right)+\Phi_{s}^{n-3} \times \Phi_{\pi}\left(\pi_{t}-\overline{\pi_{t}}\right)+\ldots+\right. \\
& \left.+\Phi_{s}^{2} \times \Phi_{\pi}\left(\pi_{t}-\overline{\pi_{t}}\right)++\Phi_{s}^{1} \times \Phi_{\pi}\left(\pi_{t}-\overline{\pi_{t}}\right)++\Phi_{s}^{0} \times \Phi_{\pi_{t}}\left(\pi_{t}-\overline{\pi_{t}}\right)\right)= \\
& =0+\lim _{n \rightarrow \infty}\left(\Phi_{\pi}\left(\pi_{t}-\overline{\pi_{t}}\right) \cdot \frac{1-\Phi_{s}^{n-1}}{1-\Phi_{s}}\right)=\frac{\Phi_{\pi}}{1-\Phi_{s}} \times\left(\pi_{t}-\overline{\pi_{t}}\right) .
\end{aligned}
$$

For instance, taking into account the Model 1, a $10 \%$ permanent inflation gap would translate into the rise of nominal interest rates by $21 \%$ $\left(\frac{\Phi}{1-\Phi_{S}} \times\left(\pi_{t}-\overline{\pi_{t}}\right)=\frac{0.21}{1-0.9} \times 10 \%=21 \%\right)$ satisfying the Taylor Principle in the long run.

Relaxing the strong assumption that the inflation gap is constant and does not depend on nominal interest rates would cause that the final increase of interest rates would be naturally smaller than $21 \%$, but so would be the inflation gap. In particular, assuming the proportionality between the changes of inflation gap and nominal interest rates, the Taylor Principle should remain fulfilled in the long run.

\section{References}

Baranowski, P. (2011). Reguła Polityki Pieniężnej dla Polski - Porównanie Wyników Różnych Specyfikacji (Monetary Policy Rule for Poland - Comparison of Different Specifications). Oeconomia Copernicana, 3.

Baranowski, P., Gajewski, P. (2015). Credible Enough? Forward Guidance and Perceived National Bank of Poland's Policy Rule. Applied Economics Letters, 23(2), 89-92, https://doi.org/10.10 80/13504851.2015.1051651 
Bean, C. (2013). Global Aspects of Unconventional Monetary Policies. Federal Reserve Bank of Kansas City Symposium, Jackson Hole.

Belka, M. (2014). Economies Need Strong Foundations. Interview, obserwatorfinansowy.pl.

Bianchi, F., Melosi, L. (2014). Constrained Discretion and Central Bank Transparency. National Bureau of Economic Research. Working Paper. No. 20566.

BIS (2012). 82nd Annual Report. Bank for International Settlements.

Borio, C., Zhu, H. (2007). Capital Regulation, Risk-Taking and Monetary Policy. Bank for International Settlements. Working Paper. No. 268.

Caballero, R., Farhi, E. (2014). The Safety Trap. National Bureau of Economic Research. Working Paper No. 19927, https://doi.org/10.3386/w19927

Campbell, J. R., Evans, C. L., Fisher, J. D. M., Justiniano, A. (2012). Macroeconomic Effects of Federal Reserve Forward Guidance. Brookings Papers on Economic Activity, 44(1), 1-80, http://dx.doi.org/10.2139/ssrn.2166310

Caplin, A., Leahy, J. (1996). Monetary Policy as a Process of Search. American Economic Review. American Economic Association, 86(4), 689-702.

Caraiani, P. (2013). Comparing Monetary Policy Rules in CEE Economies: A Bayesian Approach. Economic Modelling, 32, 233-246, http://dx.doi.org/10.1016/j.econmod.2013.01.045

Carlstrom, C. T., Fuerst T. S., Paustian M. (2015). Inflation and Output in New Keynesian Models with a Transient Interest Rate Peg. Journal of Monetary Economics, 76, 230-243, http:// dx.doi.org/10.1016/j.jmoneco.2015.09.004

Chen, H., Curdia, V., Ferrero, A. (2012). The Macroeconomic Effects of Large-Scale Asset Purchase Programmes. The Economic Journal, 122(564), F289-F315, http://dx.doi. org/10.1111/j.1468-0297.2012.02549.x

Chung H. (2015). The Effects of Forward Guidance in Three Macro Models. FEDS Notes. Retrieved: http://www.federalreserve.gov/econresdata/notes/feds-notes/2015/effects-of-forwardguidance-in-three-macro-models-20150226.html

Clarida R., Gali J., Gertler M. (2000). Monetary Policy and Macroeconomic Stability: Evidence and Some Theory. The Quarterly Journal of Economics, 115(1), 147-180, http://dx.doi. org/10.1162/003355300554692

Clarida, R., Galí, J., Gertler, M. (1998). Monetary Policy Rules in Practice: Some International Evidence. European Economic Review, 42, 1033-1067.

Coenen, G., Warne, A. (2014). Risks to Price Stability, the Zero Lower Bound and Forward Guidance A Real-Time Assessment. International Journal of Central Banking, June.

Cour-Thimann, P., Winkler, B. (2013). The ECB's Non-Standard Monetary Policy Measures the Role of Institutional Factors and Financial Structure. European Central Bank. Working Paper No. 1528.

Cúrdia, V., Woodford, M. (2009). Credit Frictions and Optimal Monetary Policy. Bank for International Settlements. Working Paper No. 278.

Davig, T., Leeper, L. M. (2007). Generalizing the Taylor Principle. American Economic Review, 100(1), 618-624, http://dx.doi.org/10.1257/aer.100.1.618

De Graeve, F., Ilbas, P., Wouters, R. (2014). Forward Guidance and Long Term Interest Rates: Inspecting the Mechanism. Sveriges Riksbank. Working Paper Series No. 292.

Del Negro, M., Giannoni, M., Patterson, C. (2012). The Forward Guidance Puzzle. Federal Reserve Bank New York. Staff Report No. 574, https://doi.org/10.2139/ssrn.2163750 
Den Haan, W. (2013). Introduction, in den Haan W., ed., Forward Guidance, Perspectives from Central Bankers, Scholars and Market Participants. Centre for Economic Policy Research, 1-21.

Eggertsson, G. B., Woodford, M. (2003). The Zero Bound on Interest Rates and Optimal Monetary Policy. Brookings Papers on Economic Activity, 34(1), 139-211.

Filardo, A., Hofmann, B. (2014). Forward Guidance at the Zero Lower Bound. BIS Quarterly Review, March.

Frömmel, M., Garabedian, G., Schobert, F. (2011). Monetary Policy Rules in Central and Eastern European Countries: Does the Exchange Rate Matter? Journal of Macroeconomics, 33(4), 807-818, http://dx.doi.org/10.1016/j.jmacro.2011.05.003

Glick, R., Leduc, S. (2012). Central Bank Announcements of Asset Purchases and the Impact on Global Financial and Commodity Markets. Journal of International Money and Finance, 31(8), 2078-2101, http://dx.doi.org/10.1016/j.jimonfin.2012.05.009

Grostal, W., Cizkowicz-Pękała, M., Niedźwiedzińska, J., Skrzeszewska-Paczek, E., Stawasz, E., Wesołowski, G., Żuk, P. (2015). Ewolucja strategii celu inflacyjnego w wybranych krajach (Evolution of Inflation Targeting in Selected Countries).. NBP: Warszawa. ISBN 978-83-941054-0-2.

Gurkaynak, R. S., Sack, B., Swanson, E. T. (2005). Do Actions Speak Louder than Words? The Response of Asset Prices to Monetary Policy Actions and Statements. International Journal of Central Banking, 1(1), 55-93.

Hsing, Y. (2005). Did U.S. Monetary Policy Respond to Exchange Rates, Long-Term Interest Rates, and the Unemployment Rate Gap? The International Trade Journal, 19(1), 67-82, http://dx.doi.org/10.1080/08853900590905766

Kahn, G. A. (2012). Estimated Rules for Monetary Policy. Federal Reserve Bank of Kansas City Economic Review, 5-29.

King, M. (1997). Changes in UK Monetary Policy: Rules and Discretion in Practice. Journal of Monetary Economics, 39(1), 81-97, http://dx.doi.org/10.1016/S0304-3932(97)00009-3.

Kool, C. J. M., Middeldorp, M., Rosenkranz, S. (2011). Central Bank Transparency and the Crowding Out of Private Information in Financial Markets. Journal of Money, Credit, and Banking, 43(4), 765-774, http://dx.doi.org/10.1111/j.1538-4616.2011.00395.x

Krishnamurthy, A., Vissing-Jorgensen A. (2011). The Effects of Quantitative Easing on Interest Rates: Channels and Implications for Policy. Brookings Papers on Economic Activity, 43(2), 215-287, https://doi.org/10.1353/eca.2011.0019

Kydland, F. E., Prescott E. C. (1977). Rules Rather than Discretion: The Inconsistency of Optimal Plans. Journal of Political Economy, 85(3), 473-491, https://doi.org/10.1086/260580

Leitemo, K., Söderström, U. (2005). Simple Monetary Policy Rules and Exchange Rate Uncertainty. Journal of International Money and Finance, 24(3), 481-507, https://doi. org/10.1016/j.jimonfin.2005.01.001

Levin, A., López-Salido, D., Nelson, E., Yun, T. (2010). Limitations on the Effectiveness of Forward Guidance at the Zero Lower Bound. International Journal of Central Banking, 6(1), 143-189.

Lim, W. B., Goodhart, C. (2011). Interest Rate Forecasts: A Pathology. International Journal of Central Banking, 7(2), 135-172.

McKay, A., Nakamura, E., Steinsson, J. (2015). The Power of Forward Guidance Revisited. National Bureau of Economic Research. Working Paper No. 20882, https://doi.org/10.3386/w20882

Mehra, Y. (1997). A Federal Funds Rate Equation. Economic Inquiry, 35(3), 621-630, https://doi. org/10.1111/j.1465-7295.1997.tb02038.x 
Meltzer, A. H. (2013). A Slow Recovery With Low Inflation. Economics Hoover Institution. Working Paper No. 13110.

Mills, T. C. (1991). Time Series Techniques for Economists. Cambridge University Press. ISBN 978-0521405744.

Morris, S., Shin, H. S. (2002). The Social Value of Public Information. American Economic Review, 92, 1521-1534.

NBP (2013). Raport o inflacji (Inflation Report), November. [Retrieved 2016-03-01] Available at: http://www.nbp.pl/polityka_pieniezna/dokumenty/raport_o_inflacji/raport_ Listopad_2013.pdf

Neuenkirch, M., Siklos P. L. (2014). When Is Lift-Off? Evaluating Forward Guidance from the Shadow. Open Economies Review, 25(5), 819-839, https://doi.org/10.1007/ s11079-014-9328-6

Orlowski, L. T. (2010). Monetary Policy Rules for Convergence to the Euro. Economic Systems, 34(2), 148-159, https://doi.org/10.1016/j.ecosys.2009.09.005

Osińska, M. (2000). Ekonometryczne modelowanie oczekiwań gospodarczych (Econometric Modeling of Economic Expectations). UMK, Toruń. ISBN 83-231-1166-9.

Popescu, I. V. (2014). Analysis of The Final Objectives Of Monetary Policy. The Case of Central and Eastern European Countries. Studia Universitatis Babes-Bolyai, Oeconomica, https:// doi.org/10.1016/S2212-5671(15)00105-7

Popescu, I. V. (2015). A Structural Analysis of Central Banks Final Objectives Prioritization. The Case of Central and Eastern European States. Procedia Economics and Finance, 20, 525-534, https://doi.org/10.1016/S2212-5671(15)00105-7

Rajan, R. (2005). Has Financial Development Made the World Riskier? National Bureau of Economic Research Working Paper No. 11728, https://doi.org/10.3386/w11728

Reinhart, C. M., Rogoff, K. S. (2011). From Financial Crash to Debt Crisis. American Economic Review, 101(5), 1676-1706, https://doi.org/10.1257/aer.101.5.1676

Richhild, M. (2015). Reactions of US Government Bond Yields to Explicit FOMC Forward Guidance. North American Journal of Economics \& Finance, 33, 217-233, https://doi. org/10.1016/j.najef.2015.04.007

Rudebusch, G. D. (2006). Monetary Policy Inertia: Fact or Fiction? International Journal of Central Banking, 2(4), 85-135.

Rzońca, A. (2014). Kryzys Banków Centralnych - Skutki Stopy Procentowej Bliskiej Zera (Crisis of the Central Banks - the Results of Zero Lower Bound on Nominal Interest Rates). Warszawa: C.H. Beck. ISBN 978-83-255-5544-3.

Svensson, L. E. O. (2010). Policy Expectations and Policy Evaluations: The Role of Transparency and Communication. Sveriges Riksbank Economic Review, 2010(1), 43-78.

Svensson, L. E. O. (2015). Forward Guidance. Centre for Economic Policy Research. Discussion Papers No. 10669.

Swanson, E. T., Williams, J. C. (2014). Measuring the Effect of the Zero Lower Bound on Mediumand Longer-Term Interest Rates. American Economic Review, 104(10), 3154-3185, https:// doi.org/10.1257/aer.104.10.3154

Sznajderska, A. (2012). On Asymmetric Effects in a Monetary Policy Rule. The Case of Poland. National Bank of Poland. Working Paper No. 125, https://doi.org/10.2139/ssrn.2163516

Taylor, J. B. (1993). Discretion versus Policy Rules in Practice. Carnegie-Rochester Conference Series on Public Policy 39, 195-214. 
Taylor, J. B., Williams, J. C. (2010). Simple and Robust Rules for Monetary Policy, in Friedman, B. M., Woodford, M., ed., Handbook of Monetary Economics. Elsevier B.V., pp. 829-859.

Ueda, K. (2012). Japan's Deflation and the Bank of Japan's Experience with Nontraditional Monetary Policy. Journal of Money, Credit and Banking, 44, 175-190, https://doi. org/10.1111/j.1538-4616.2011.00485.x

Vašiček, B. (2009). Monetary Policy Rules and Inflation Process in Open Emerging Economies: Evidence for 12 New EU Members. William Davidson Institute. Working Paper No. 968, https://doi.org/10.2139/ssrn.1490069

Walsh, C. E. (2013). Announcements and the Role of Policy Guidance. Federal Reserve Bank of St. Louis Review, 95(6), 575-600.

Walsh, C. E. (2015). Goals and Rules in Central Bank Design. International Journal of Central Banking, 11(S1), 295-352.

White, W. R. (2013). Ultra Easy Monetary Policy and the Law of Unintended Consequences. Real-World Economics Review, 63, 19-56.

Williams, J. C. (2013). Forward Policy Guidance at the Federal Reserve, in Wouter den Haan ed., Forward Guidance, Perspectives from Central Bankers, Scholars and Market Participants. Centre for Economic Policy Research, pp. 43-47.

Wojtyna, A. (2004). Szkice o polityce pieniężnej (Drafts on Monetary Policy). Polskie Wydawnictwo Ekonomiczne, Warszawa. ISBN 8320815312.

Woodford, M. (2003). Optimal Interest-Rate Smoothing. Review of Economic Studies, 70(4), 861-886, https://doi.org/10.1111/1467-937x.00270

Woodford, M. (2012). Methods of Policy Accommodation at the Interest-Rate Lower Bound. Revised draft of a paper presented at the Federal Reserve Bank of Kansas City Symposium on "The Changing Policy Landscape," Jackson Hole, Wyoming, 185-288. 